\title{
Human Security Paradigms and Economic Crisis in first year of the North Caucasus Federal District
}

\author{
Tiago Ferreira Lopes \\ Institute of Social and Political Sciences, Lisbon Technical University, Portugal
}

The decrease in insecurity in the North Caucasus during the first eight years of the $21^{\text {st }}$ century was achieved with the help of federal money used to amnesty soldiers and to pacify ethnic leaders' ambitions. But circumstances changed after Dmitry Kozak's announcement that the federal budget for the entire region would decrease significantly. As all the republics in the North Caucasus are dependent on federal aid of no less than 50\% (in Ingushetia, Chechnya and Dagestan dependence is superior to $80 \%$ ), such cut represented a politically potential danger.

The main goal of the article is to present a deeper understanding of the potential link between the international and regional economic dynamics and the current acceleration of social disruption in the North Caucasus region. The paper explains how ethno-political and transition studies can benefit from the inclusion of the economic dimension into the analysis, and so it clarifies the importance of a bi-level analysis using two concepts: economic society and economic security. The paper employs the concepts of economic security and economic society to perform a richer and innovative analysis.

Keywords: Human Security, North Caucasus, Insecurity, Insurgence, Ethno-politics

\section{Theoretical framework}

T $\mathrm{n}$ the literature, transition and ethno-political phenomena are more often linked

to political and social features, even with historical legacies or anthropological data, than to economic data. According to Paul Blokker, "until the end of the 1990s, the debate on 'transition' was dominated by approaches that shared a number of elementary 
assumptions on the general nature of social change" (Blokker, 2005: 504), which is generally downgrading the real importance of economic features. The majority of authors studying transition processes and ethnic politics tend to look at economy only as a secondary element of analysis. However, if we take in stock that "the most fundamental human interest, it is argued, is the maximization of life chances, from which flow the instrumental pursuits of wealth, security and power" (Hale, 2008: 3), we can begin to understand the real importance and impact of economy in the political transitions all over the world. If economy, that is the path to achieve wealth, is one of the fundamental human interests, its absence as a central element of analysis in ethno-political or transition studies undermines the conclusions about the multiple paths contemporary societies are threading.

With this paper, we set out to connect economy with ethno-political and transition studies focusing on the impact of the global crisis upon Russia and its consequences for the North Caucasus insurgency. In order to approach these topics, we will make use of the concept of human security in a double manner: (1) as a mediator between ethno-political and transition studies, on the one hand, and economic dynamics, on the other; and (2) as a trigger for more sophisticated analyses. Crucially, the paper aims at probing whether there is a connection between the global crisis beginning in 2007 and the upsurge in the North Caucasus violence.

As Henry Hale (2008) states, economy is important to ensure the maximisation of human life. In line with that argument, we can assert that the degree of economic wealth of a country or a region influences the development of every transition process. In this matter, Juan Linz and Alfred Stepan assert that "the final supportive condition for a consolidated democracy concerns the economy, or rather the arena we believe should be called "economic society" (Linz and Stepan, 1996: 11). The authors state that truly free and democratic societies are those that show open and free markets promoting the values of equality, democracy and competitiveness. While the merits of open markets and command economies can be argued and debated, we can assume as a starting point for this paper that "economic interests may play a role in ethnic conflict" (Horowitz, 2000: 106), urging the necessity to include a more sophisticated analysis of this dimension into ethno-political and transition studies research.

The sphere of economic society - abstractly conceived of, under a veil of ignorance as it were - is certainly made up of institutions, regulations and norms, but there is no direct state control and no protecting mechanisms. The bottom line is the ability of the actors to create value that will define the winning and losing sides of the economic game with no regard to the ethnic origin or the social status. That's why for liberals the market is a force for inclusion and integration, depoliticised as it were, and for some the actors 
should even enter the contract under the veil of ignorance in order to prevent unfair inequalities arising from the social background and personal handicaps.

In line with this, it is possible to assert that the workings of this depoliticised arena in transitional societies might be able, at least partially, to promote more motivation towards integration (or at least to non-violent coexistence and non-violent secessionism) because all actors have a basis to be equally considered in the economic game. In Henry Hale's (2008: 161) perspective, the economic workings also play a political and motivational role, considering that "those ethnic regions that stand to gain the most from union, therefore, will tend to be willing to take the greatest perceived chance of exploitation, whereas those that stand to gain the least will be among the first to 'jump ship' as the perceived exploitation rises".

We can then assume that the degree of functionality and openness of economic societies is directly linked to the ability to promote integration, or at least guarantee non-violent coexistence or even non-violent secessionist or separatist projects. Besides the integrative function, an open and non-state-guided market is also more capable of accommodating the divergent interests of ethnic elites transforming a potential enemy (the central state) into an acceptable and desirable broker. At this point, we can argue that "transitions clearly were most likely to occur in countries at the middle and upper-middle levels of economic development" (Huntington, 1993: 62). Since that, those countries could easily ensure political as well as economic pluralism.

In this dialectic relation between economic societies' stage of development and successful transitions, ethnicity tends to be rationalised or instrumentalized as a "strategic choice by individuals who, in other circumstances, would choose other group memberships" (Bell, 1975: 171). Integration or separatism will be decided through a calculus of gains and losses that tend to make richer regions more prone to separatist drives, since they have most to lose by prolonging an attachment to a certain non-homogeneous state apparatus.

This argument could explain why the poor Karakalpakstan region wasn't able to secede from Uzbekistan and has gradually refrained its demands short of independence. And it also elucidates the motivation of Catalonia to achieve greater autonomy, since it is the most economically developed and sustainable of all Spanish autonomies. But it doesn't explain why the Trans-Dniester insists in its separatist stalemate with Moldova. Even being Europe's poorest country, the Moldovan republic is in a better economical condition than the separatist region.

Although a more rationalist-economicist perspective is suitable to some separatist cases, we should not ignore that "the emergence of democracy [and subsequent open and inclusive societies] is not a by-product of economic development" (Przeworski and 
Limongi, 1997: 177) and, therefore, "many separatist groups all over the world have proceeded to fight for ethnic autonomy despite the costs" (Horowitz, 2000: 132). In our understanding, human motivation is not linear and rationality could be accounted for in several ways, for example, instrumentally and non-instrumentally.

It is crucial to underline, however, that the path towards integration, secessionism or separatism is not only influenced by the ability to establish an open market, and to build an economic society, but by a larger set of different factors. Despite the difficulty to measure the impact of economic behaviour and its influence upon integration, secessionism or separatism, it is generally consensual that the more difficult it is to build an economic society, the more the levels of ethno-political uncertainty tend to increase and feelings like loyalty, solidarity and cooperation tend to deteriorate.

Although it is inaccurate to assert about a strict casual relation between the establishment and development of economic societies and the tendency towards integration, secessionism or separatism, it is also incorrect to ignore that states where economic societies are virtually non-existent tend to live without economic security, which is one of the seven dimensions of the UN's Human Security concept. Originally put forward by the PNUD in 1994, "the concept of human security represents a powerful, but controversial, attempt by sections of the academic and policy community to redefine and broaden the meaning of security" (Baylis, Smith and Owens, 2008: 492). With this kind of approach, experts, analysts and policymakers have started to broaden their focus and concerns and move them away from the threats states pose to states.

This multidimensional conception of "security" proposed by the UN gives a "response to the complexity and the interrelatedness of both old and new security threats (...) Such threats tend to acquire transnational dimensions and move beyond traditional notions of security that focus on external military aggressions alone" (United Nations, 2009: 16), leaving aside such important challenges to contemporary societies as economic crisis, persistent and endemic poverty, and social unrest.

Presently, the concept of "human security" continues to be under an enormous debate that does not fall under this paper, but it almost unanimously accepted that "when people are uncertain where the next meal will come from, when their life savings suddenly plummet in value, when their crops fail and they have no savings - human security contracts" (Commission on Human Security, 2003: 73), since this type of disruption causes instability that tends to raise the prospects of violence and to the emergence of exclusivist notions of psychosocial identity such as ethnic separatism.

Through a "human security" perspective, we look more attentively to threats and vulnerabilities of human beings and sub-state communities, knowing that "human insecurity can arise from want of a job, lack of access to food, threats to health, poor infrastructure, 
oppression by the state, social discrimination and prejudice, crime, and so on" (Human Development Network, 2005: 2); in this regard, it is already plausible to argue that in advanced and functional economic societies, economic security (micro level) and human security (macro level) tend to be strengthened.

The relevance of a correlated analysis using the concepts of economic society and economic security is practically unquestionable if we recall that "poverty is one of the most serious and persistent threats to human security (...) [since] it affects all aspects of human security understood in terms of "freedom from want"” (Unesco, 2008: 66). Developed economic societies are more able to downsize the prospects of poverty and, consequently, to raise the variables that ensure a human-secure environment. Summing up, this is why we consider that a new focus on the economic performance is of much help, towards a new understanding of the path chosen by political elites in transitional societies, whether this implies a transition towards democracy or autocracy, towards integration or separatism.

Before concluding the theoretical part of this paper, we should notice that economic society and human security cannot be mixed together, even if they both share in the prerequisites of the economy realm. Economic society is the institutional domain affecting the transitional path of states and other political entities towards a variety of different social and political futures. In this line, economic society represents a macro level of analysis. Alternatively but complementarily, human security represents a more micro level of analysis to human vulnerabilities that are conceived as a challenge to the more institutional setup. They are conceived of as unnecessary limitations to the freedom from want, wherein every human needs to fulfill his or her inherent dignity.

Throughout the paper, we make use of these two levels of economic analysis in order to ensure a better understanding of the phenomena affecting the newly created North Caucasus Federal District. The main aim of this paper is not to put forward political solution though, even if it hints at what could be perceived as draft suggestions to specific problems. The remainder of the paper is as follows. The next section offers a short historical synopsis of the paths that both the Russian Federation and the North Caucasus economies have taken in the last twenty years of their recent history. After that, we will probe how the disruption caused by the economic global crisis in the enfeebled economies of the North Caucasus Federal District could help in explaining the upsurge in regional violence.

\section{Historical synopsis of the Russian Federation and North Caucasus economies}

In order to comprehend the evolution of the economic state of affairs in the newly created North Caucasus Federal District and its probable connections with the growth of 
separatist demands and regional violence, we should start to look to the Russian Federation's recent economic history. Broadly speaking, in the last twenty years (1991-2010), the economy of the Russian Federation has undergone profound transformations. The first ten years immediately after the implosion of the Soviet Union were dramatic. Under Boris Yeltsin's rule, the (important) ability of the Russian state to collect taxes was reduced so much that "between 1989 and 1997, state revenues fell by nearly 45 per cent" (Freeze, 2009: 470). As a direct consequence, there was a disruption in major social services such as education and culture, but there were also cuts in security, law enforcement and public health budgets.

The Russian Federation's feeble economy didn't guarantee stability or even daily certainty, and suffered from the exponential growth of bribes and illegal parallel markets. Yeltsin implemented several measures, the most famous being the disastrous Gaidar's "shock therapy", which proved to be ineffective given that "between 1991 and 1998, Russian national income shrank by about half, one of the steepest peacetime falls ever recorded anywhere" (Wasserstein, 2007: 714), not even comparable with the economic falls of the United Kingdom, Germany or the United States during the 1930s Great Depression. On one side the Federation struggled to acquire control over tax collection and to regain international trust in order to seek foreign loans; on the other side, "there were persistent constraints upon entrepreneurial innovation. The government did precious little to impose the rule of law" (Service, 1997: 526), with there being a significant growth in internal corruption and a decrease in foreign investments as a result.

Yeltsin's final, desperate measure, the "loans-for-shares", collapsed in the financial crisis of August 1998, a period also known as Catastroika. In sum, in the first decade after the implosion of the Soviet Union, the economy showed a continuous weakness and sheer incapacity to recover both on domestic and international levels. To have a more accurate idea of the weaknesses of the Russian Federation's economy, it is important to know that in only six years (1991-1997), "the GDP dropped a staggering 43 per cent (...) [as a result of that], Russia's per capita GDP in 1999 was only 4,200 dollars - slightly more than Botswana (3,900 dollars), but less than Namibia (4,300 dollars) and Peru (4,400 dollars)" (Freeze, 2009: 475), states that are usually approached as poor and part of the Third World.

With a frail and, in some moments, uncontrolled economy, it was more than expected that "poverty rates rose significantly over the transition years (...) The Russian Bureau of Statistics reports that poverty increased from $10-12 \%$ in 1990 to $25 \%-33 \%$ in 2000 " (Brookdale Institute, 2003: 11), threatening the economic security of the Russian population and strengthening the claims to greater sovereignty of several ethno-political leaders - not just in North Caucasus, but also in Tatarstan, Bashkortostan and Sakha republic. 
Without the capacity to fulfill basic daily needs, populations tended to become more willing to adhere to nationalist and separatist groups and to promote or even practise violent acts.

Overall, "Yeltsin's choice to privilege economic restructuring over democratic state restructuring weakened the state, weakened democracy and weakened the economy" (Linz and Stepan, 1996: 392), threatening the transition towards democracy in itself and jeopardising the production of human security. The disruption in the economy produced a destructive wave in all other areas from public health to culture and to public security. At the end of the millennium, the situation in the Russian Federation neared total chaos. Yeltsin's unfruitful reign in the first decade after the collapse of the Soviet Union was followed by the arrival of a new strong and charismatic leader: Vladimir Putin.

Practically unknown to the majority of the social and even political circles in Moscow, the former director of the secret police FSB (Federal'naya sluzhba bezopasnosti Rossiyskoy Federatsii) and former director of the Security Council started a progressive economic transformation. There were several economic reforms started under Putin's rule, but none of them used policy measures as extreme as the ones chosen by his predecessor. The reforms that were implemented proved to work: from 2000 to 2008, the GDP of Russia in Purchasing Power Parity (the PPP corrects distortions of nominal currency values) rose 202\% from 1,120 billion dollars to 2,266 billion dollars (Index Mundi, 2011), upgrading the Federation's economic situation from a feeble condition to the eighth largest economy worldwide.

Nevertheless, we must never lose from sight the rise of revenues for the trade in commodities in order not to overstate the reach of Putin's policies. The majority of economic data prior to the recent economic global crises was favourable to Putin's administration though. In the first decade of the twentyfirst century, the per capita GDP rose from 4,200 dollars (2000) to 14,600 dollars (2008), allowing a general improvement in life conditions, across the Russian Federation. Rising income made possible the allocation of money to health, education, social security, and to fight poverty. According to the World Bank, poverty rates in Russia decreased from 19.2\% in 2002 to 11.1\% in 2006 (World Bank, 2012)

What some call the 'miracle' orchestrated by a certain strategic vision of Putin's was also facilitated by "the red-hot global economy of those years (1999-2008), which generated a sharp surge in demand for commodities, especially hydrocarbons, metal, and timber - Russia's principal exports" (Freeze, 2009: 498) to the global market. Another essential factor to Russia's rapid economic recovery was the depreciation of the ruble after Catastroika, which made Russian products less expensive and thus more competitive, an occurrence similar to China's economic success that was partially achieved because of the 
depreciated Yuan and Chinese products compared to those sold in Pounds, Euros, Dollars or Yen.

Despite this major economic growth, some areas continued to be underdeveloped. Justice reforms proved to be shortly effective and were sometimes even simple rhetorical exercises of the Kremlin's newest tsar. Federal and regional bureaucracy also hadn't achieved a high level of proficiency. Putin's first priority was to stabilise the domestic markets and to improve the international image of the Russian Federation in political and economical spheres. However providential and effective, Putin's economical choices had produced an extraordinary dependence on commodities: "In 2009, Russia was the world's largest exporter of natural gas, the second largest exporter of oil, and the third largest exporter of steel and primary aluminum." (Commodities Street Journal, n.d.)

Russia's incapacity to diversify its exporting portfolio transformed it into a fragile state in a scenario of global economic crisis, like the one spreading throughout the world in the second semester of 2008. At the beginning the crisis produced a sharp reduction in the oil prices. In order to prevent a new Catastroika, "the government had to raid the foreign exchange reserves (...) [that had] shrunk from 598 billion dollars to 426,5 billion dollars by early January [2009], and dropped to 388 billion a month later (a decrease of 35 per cent)" (Freeze, 2009: 524). These most needed initial measures weren't enough to prevent the depreciation of the ruble, and had slowed down growth in the Russian Federation.

The cycle of economic transformations and the rhythm of its multiple effects weren't identical in all regions of the Russian Federation. In the specific case of the North Caucasus, the economic history of the last 20 years was as plain as it was dark. Since the collapse of the Soviet Union, "political killings and inter-ethnic discord afflicted virtually every Russian republic" (King, 2008: 232) in this region in addition to the revival of ethno-national separatism and the explosion of Islamic extremism. In a paper published in 2009, Sergey Markedonov signalled that "in the Russian North Caucasus, the main challenge to regional security is posed by illegal armed formations, acts of sabotage, and terrorist jamaats" (Markedonov, 2009: 14) that have been revived in the last three years across the entire North Caucasus.

The never-ending socio-political unrest had such atrocious consequences on the economy that "the extent of this economic collapse is difficult to grasp, as it had few precedents in recent history (...) by the mid-1990s, up to half of the population of the South Caucasus lived below the poverty line, and though less reliable, figures in the North Caucasus were even worse" (Cornell and Starr, 2006: 36). Adding to this dramatic picture, they reached the highest unemployment rate in the entire Russian Federation. The combination of these factors undermines the economic security of local populations, making it easier to adhere to extremist Islamic movements or to ethno-national separatist projects. 
In comparative terms, the North Caucasus republic with the lowest rate of unemployment in 2008 was Adygea, reaching 8.5\% ${ }^{1}$ among a total population of more than 440,000 citizens. Ingushetia's republic recorded the highest regional rate of unemployment, with $47.4 \%$ of the population (comprising fewer than 500,000 citizens) being without a job (Körbel, 2009: 2). According to Thomas Körbel (2009), young people unemployment in Ingushetia was even higher, above $70 \%$. These rates are partially responsible for the upsurge in regional violence. Without hope for a better future, being deprived of a regular job and proper living conditions, youngsters tend to adhere to extremism or separatism as a way to improve their possibilities, to achieve the maximisation of life options.

Despite the levels of violence and political defiance, the unstable North Caucasus is economically important to the Russian Federation because it ensures direct access to both the Caspian and the Black seas. The shocking fact is that, even with this potential relevance, the North Caucasus "is regarded as the least attractive region in the entire country for foreign investors" (Matveeva, 1999: 44) because of this continuous socio-political instability. In the years of the Yeltsin presidency, the North Caucasus underwent a gradual deterioration of living conditions as a consequence of the Russo-Chechen wars as well as other ethnic conflicts (those of North Ossetia and Ingushetia and in Dagestan). The parade of conflicts partially explains why since 1991, it has "constituted the poorest regions of the entire Russian Federation" (Coene, 2009: 190), with the overall lowest indicators on socioeconomic development, excluding birth rate (the highest in the entire Federation).

The prospects of a change in the beginning of the new millennia were soon dropped. In fact, "under Putin the region has not beneficiated significantly from the oil and gas" (Melvin, 2007: 44) productions in the region. The need for heavy investment to modernise regional refineries and factories and the unattractiveness of this area to foreign investment was responsible for the actual decadence. It is a strange historical irony that the first region of the Soviet Empire where oil was exploited, the region that in the 1920s accounted for more than $10 \%$ of the Soviet production in oil, "has lost its prominence as a fuel base. In the early 1990s, it accounted for 1,8 per cent of the crude oil and 0,8 per cent of gas production" (Matveeva, 1999: 44), with the current figures supposedly being even lower.

The primary sector in the North Caucasus is also heavily affected by this endemic underdevelopment. For example, "agriculture seems to work somehow, but only to the extent of providing some basic food products to the region" (Liono, 2000), giving no prospects to business opportunities in this sector. The socioeconomic relevance of agricultural activities in the region can be heightened if we remember that "by the end of the 1990s, only one region [Northern Caucasus] had more than four private farms per 1,000 persons" (Wegren, 2003: 44) in the entire Russian Federation territory. 
Differently, the Ossetian alcohol production is a significant business representing almost $20 \%$ of the raw materials placed in the Federation market for the production of alcoholic drinks. Although we can argue that this is a small and geographically limited success, we have to agree that this is "a satisfactory figure for a region where money does not fall from the skies" (Liono, 2000). The tourism sector also has great economic potential, especially in the republic of Kabardino-Balkaria because of the ski resorts in the Elbrus. The reality is that "tourist facilities have only 25\% occupancy rate" (Liono, 2000), which is mostly ensured by domestic tourists and by foreigner tourists from Turkey, Georgia and Azerbaijan.

Several researchers criticise the lack of a multilevel strategy in Putin's policies for the regions that are as focused on security issues as unable to solve them. The critical fact is that "the absence of truthful programs of nation building and economic development in this region is denying an improvement of the current situation" (Körbel, 2009: 3) and is even creating new problems, such as the previously mentioned phenomenon of juvenile delinquency that has flourished as a consequence of the lack of jobs. Some measures of the central administration have deepened some economic structural problems.

Although the Federal Administration has tried to circumvent those hindrances through the Regional Support Fund, given that "the largest net recipients tend to be the relatively rural, less developed regions of the North Caucasus" (Smith, 1999: 195), the fact is that the region continues to be unable to overcome its chronicle underdevelopment. One of the main reasons for this scenario can be attributed to the absence of urban settlements. "According to the data of the population census of 2002 in the North Caucasus, we see no big cities" (Lordkipanidze and Totadze, 2010: 162) except for Makhachkala (capital of Dagestan) that overcomes half a million inhabitants.

In this regard, there is little surprise when we perceive that we have in the North Caucasus the $2^{\text {nd }}$ (Ingushetia), $4^{\text {th }}$ (Dagestan), $6^{\text {th }}$ (Chechnya), $7^{\text {th }}$ (Kabardino-Balkaria), $11^{\text {th }}$ (Karachaevo-Cherkessia), $14^{\text {th }}$ (Dagestan), and $15^{\text {th }}$ (Adygea) most subsidised regions (Perovic, 2006: 7) in a total of 83 federal subjects (there were 88 subjects until the administrative reform of 2008) composing the Russian Federation. The effort to keep those regions artificially stabilised through federal monetary subsidies, which account from more than 58\% (Adygeia) to almost 90\% (Ingushetia) of the subjects' budget, might be in peril due to the world crisis scenario like the one faced by the Russian Federation since the second semester of 2008. From here on, we would like to stress how the disruption caused by the economic global crisis in enfeebled economies like the ones in the North Caucasus Federal District could help to explain the upsurge in ethnic violence. We will use the concepts of economic society and economic security to guarantee a proper bi-level analysis on ethno-political and transition phenomena. 


\section{Economic society, economic security and ethno-politics in the North Caucasus}

The North Caucasus is one of Russia's most distinctive regions. It encompasses one of the thirteen military districts ${ }^{2}$, one of the twelve economic regions ${ }^{3}$, and it has also been the eighth federal district since 19 January 2010. Until that date, the North Caucasus territories were inside the Southern federal district that after the split has only maintained the Ciscaucasian constituencies of Adygea republic, Krasnodar krai and Kalmykia republic. In a speech to the Federal Council on 12 November 2009, Dmitri Medvedev "argued that the region's problems derive in the first instance from economic backwardness, unemployment, and high-level corruption" (Caucasus Report, 2010), a factor that undermines the confidence of the local population in federal and regional institutions.

The economic factor is so decisively important to begin to solve the numerous problems of the region that even the choice of the governor to the new federal district took the fact into account. The appointee, Aleksandr Khloponin, is a former businessman with a short but very successful political career in the Siberian Federal District. The nomination of Khloponin can be understood as the Kremlin's statement that economic issues should be the primary focus of power. Aleksandr Khloponin knows that he urgently "needs to create a normal living environment in the North Caucasus, in particular improving socio-economic environment" (Jackson, 2010) in order to ensure economic security and to promote the development of a truly economic society. The North Caucasus Federal District summons all four major threats to human security: besides the high rate of unemployment, it has "insufficient economic resources, unstable economic flows and asset losses" (Commission on Human Security, 2003: 73), creating a bulk of circumstances that undermine the narrow confidence of the locals in Moscow's capability to solve real problems.

Despite the pressing necessity to solve these economic security vulnerabilities, only in the beginning of July 2010 did the first governor of the North Caucasus Federal District present his plan to solve the region's socioeconomic problems, with an expected prominence on economic and financial measures. In the document presented to Medvedev (at that moment, President of the Russian Federation), Khloponin "proposes launching priority projects, along with improving the overall investment climate in the North Caucasus in 2010-2012 and starting an 'active growth phase' in 2013-2025" (Dzutsev, 2010).

The two major proposals put forward by Khloponin were a huge investment in transport infrastructures ${ }^{4}$ and a downgrade or even an elimination of taxes on economic initiatives developed in the region. Despite their merit, these two initiatives are in jeopardy mainly because of the effects of the global crisis on the Russian Federation's central budget. The development of the North Caucasus transport infrastructures requires big sums 
of money that only Moscow could ensure to the local government. Prior to the global crisis, this wouldn't have been a problem: the amounts of money given to subsidise the republics' inefficient socioeconomic programmes ${ }^{5}$ could easily have been diverted to this kind of specific project.

The global crisis has introduced a new degree of complexity and has even produced some incongruence and contradiction in the political speech. In September 2009, Dmitry Kozak, the Deputy Prime Minister and former governor of the Southern Federal District, stated that the "Russian government plans to cut subsidies to the republics of the North Caucasus" (Goble, 2009) in order to invest that money in other regions. However, by mid-July 2010, Khloponin was demanding more funds from the Kremlin to develop the economy of the North Caucasus. To be accurate, no substantial numbers were given either about the amount of money to be cut or on the timeline to apply those cuts. But it was crucially made sure that the cuts were inevitable.

This double-faced discourse from political leaders produces at least confusion in the local population. How can someone ask Moscow for money if Moscow has said beforehand that money was ending? Surely Khloponin knows that in the near future, "Medvedev and Putin might be hard pressed to rationalize such a huge budgetary outlay on this rebellion region, whose inhabitants are racially maligned by a significant portion of [the] Russian society" (Leahy, 2009). This is the same society that, at the same time, does not believe in any kind of mid-term success in the region and that has been called onto the polls to elect a new president. Even if the Kremlin could ensure the amounts of money needed to fulfill Khloponin's ambitious programme, there is another barrier ahead: republic heads/presidents $^{6}$ and ethnic leaders. To ensure the proper execution of the investment programme proposed by the North Caucasus Federal District governor, the decisional power would have to be concentrated in Khloponin. But the condition for that to happen is that "Moscow will have to break up the local government circles and redistribute power, something that is hard to do without jeopardizing an already unstable situation" (Dzutsev, 2010) in a region where local leaders have an almost absolute power in economic and social policies already menaced by the mere presence of the Kremlin-appointed governor.

The promises of Khloponin on heavy investments in transport infrastructures and factories across the North Caucasus as a tool to fight the insurgency had a pernicious effect. On 22 July 2011, the chief engineer for the Dagestan's company Sulaksky Hydro-Energy Cascade was abducted following the attack on the Baksan hydroelectric plant, which was located at the Kabardino-Balkaria republic and perpetrated by a group of six militants. At the same time, the numbers of terrorist attacks in Dagestan's railways have grown during the last few months. These attacks have a symbolic message stating that economy is not the major problem to solve in the North Caucasus. Insurgency fighters 
are battling for political representation, and simple economic measures will not stop their demands. Khloponin's socio-economic programme is perceived as a challenge to which they've given a strong and bloody answer.

Going back to the subject of the predictable downsizing of federal budgetary aids, it is important to stress one more issue that can contribute to the upsurge of violence in the North Caucasus. The reduction of the money received from Moscow would make it much harder to achieve regular processes of loyalty production. Until recently, "federal subsidies have facilitated the process of amnestying former guerrillas" (Leahy, 2009) integrating these men into the republic's security forces, one of the most secure and well-paid jobs in the region. With scarce money and the ambition to invest in other structural areas, these programmes would become difficult to maintain and their attractiveness would consequently decay.

We shouldn't judge lightly the reasons why this kind of scheme to combat insurgency ranks is being contemplated by the Kremlin. From an anthropological perspective, we have to take into account that "the Caucasian traditions demand that every man should take an active part in providing his relatives with the necessary resources for living" (Liono, 2000), no matter what kind of activities he has to do to achieve those precious resources. Accomplishing this paternalistic obligation is a question of manhood and honour, two structural values in the North Caucasus societies.

This societal demand on males aligned with "systemic corruption along with stat despotism and a culture of impunity" (Halbach, 2010: 15) are fomenting the growth of a "shadow economy" in the North Caucasus. Because this is a phenomenon as difficult to follow as poorly studied, we have to focus on its effects instead of looking at its dynamics. According to Arbakhan Magomedov, "illicit economic activity contributes to a "shadow state", encourages corruption and undermines the sustainability of economic development" (Jackson, 2010), which is in so much need in this Russian region.

The apparent merge on less legal economic and political activities is a heritage of the Russian influence in the region, namely Patrimonialism. Due to the Patrimonialism influence in the North Caucasus, we have several local regimes "where the rights of sovereignty and those of ownership blend to the point of becoming indistinguishable" (Pipes, 1995: 22-23), making it difficult, if not almost impossible, to reach any kind of endurable economic society, which could provide economic security and stimulus to a stabilisation of the situation and an acceleration of the integration.

According to Douglas Blum, "Putin's policies at home and abroad reflect a particular conception of the state, one that is historically rooted with imperial Patrimonialism" (Blum, 2008: 353), in which the value of entrepreneurship and innovation is substituted by the need to satisfy clienteles and loyalists. To sum up, "we have few doubts that the 
national economic system in Russia fashions a type of patrimonial capitalism, resulting from the political Patrimonialism existent in the institutions and power relations in Russia" (Freitas, 2012: 2), with there being a special occurrence in the North Caucasus. We have to have in mind that all political elites in public positions need to be confirmed by the Kremlin, and at the same time, Moscow needs to please local political elites in order to diminish regional discontentment and resentment.

So far, we can state that all North Caucasus republics have a feeble "economic society" as their very best scenario, disrupted by a shadow economy, by continuous ethnic disputes and by insurgency attacks. Even more concerning is the sheer incapacity of the federal and regional institutions to improve the already bad situation plundering the economic security of local populations. It is impossible to assert that there is human security, or even economic security, when even the traditional threats to the state security are out of control.

Moving forward, it is also important to centre our attention on the numbers concerning violent insurgency incidents and the death toll resulting from those incidents. According to a recent report of the Center for Strategic and International Studies, the number of violent incidents registered in the first four months of 2010 was $5 \%$ lower than the number of violent incidents recorded last year in the same period: decreasing from 291 violent incidents registered in 2009 to 283 violent incidents recorded this year (Mendelson, Malarkey and Moore, 2010: 7).

At a first glance, it appears that the insurgency movement had not grown but stabilised. However, we should complement this first indicator with a second one: death toll. In 2010, the decrease in 5\% on violent incidents recorded during the first four months of the year had resulted in a growth of $16 \%$ in the number of deaths, compared with the same time period in 2009. The result of the violent incidents has moved from 183 deaths reported in 2009 to 219 in 2010 (Mendelson, Malarkey and Moore, 2010: 11). From this data, we can conclude that the number of violent incidents has slightly decreased its frequency but has grown up in intensity and mortality.

How could such an outcome be related to the economical plight of the republics in North Caucasus? It is expected that violence grows when the living conditions are perceivably eroding, especially in societies without job opportunities, with insufficient and mostly ineffective social services, and where the central state is seen by a large majority of the ethnic populations as the enemy. Additionally, we should not forget that men are obliged to fulfill the basic family needs, even if young men are the most affected group by unemployment and by the economic continuous underdevelopment. There are no coincidences when we see that the most subsidised region with the higher rate of unemployment (Ingushetia) is also the second most deadly (with 290 registered occurrences) of all the 
subjects composing the North Caucasus Federal District. Dagestan, the most dangerous and deadliest of the North Caucasus republics (surpassing 320 confirmed occurrences), is the second most subsidised republic with the second highest unemployment rate.

Reinforcing our argument and understanding the perilous situation is the "Russian Prime Minister, Vladimir Putin's plan to create 400,000 jobs for North Caucasus residents over the next ten years" (Vatchagaev, 2010). To the majority of the political analysts and experts, these statements were made under the pressure of the growing destabilisation of North Caucasus, at a time in which the hosting of the Sochi Winter Olympics in 2014 and of the World Football Championship in 2018 is getting closer. Putin's declarations were vague about when the job creation would start and vaguer about which resources from the federal budget would be allocated to accomplish that ${ }^{7}$. The importance here is that Putin knows that North Caucasus' economic plight must be improved in order to guarantee economic security to local populations and, consequently, to increase the levels of loyalty to the Kremlin.

Once again, it is true that "unemployment and poverty may be factors in the rise of instability, but they do not explain the complex nature of violence in the region" (Melvin, 2007: 45), where almost fifty different ethnic groups cohabit with different and mostly divergent interests. We can even argue that, to some extent, the prolongation of insurgency could be linked to the "lack of openness, incompetence and unwillingness to hold a dialogue with opponents" (Markedonov, 2009: 52), phenomena that have characterised Russian politics since the first military campaigns launched in Astrakhan in the sixteenth century ${ }^{8}$. From this macro perspective, the unsuccessful economies of the North Caucasus are just a contributive factor to the resurgence of insurgency. The capacity to establish an economic society is vital to the transitional path towards democracy and social stability, but "it is often difficult or impossible to make systematic statements about the effect of economics in democratization processes" (Linz and Stepan, 1996: 77). In simpler words, economic dynamics could produce socio-political phenomena if and when they are related with several other factors.

In the specific case of the North Caucasus, economy surely plays an important part but is not the sole factor; this is if we take into account that even during the most peaceful years (2000-2007), the regional economies fared pretty badly. As we have argued elsewhere, ${ }^{9}$ the growth of social and political instability and the rebirth of ethno-religious nationalisms are the result of a sum of different structure and conjuncture factors. Economy (and the building of an economic society) is part of the problem but does not in itself account for the phenomenon under analysis. 


\section{Conclusion}

The situation in the North Caucasus will surely be worse after the announced cuts to the budgetary aid to all North Caucasus republics. At a different level of analysis, we can conclude that the legacies of the global crises will decrease the already feeble guarantee of human security in the region. The expected decline in human security will most probably degenerate in a dangerous uncertainty, making it more accrued in an already critical situation. This is pretty much a real picture of what could happen in the near future in the North Caucasus. As Bronislaw Geremek stated:

It has rightly been said that poverty does not necessarily generate terrorism, since terrorists also come from among the privileged. It is nevertheless true that terrorism takes advantage of misery, knowing that despair creates favourable conditions for terrorist projects and actions. (Commission on Human Security, 2003: 74)

Loyalty can't be ensured (or even demanded) when the basic needs of the local populations are not guaranteed. Knowing that "the average all-Russia rate was 7.3 unemployed in 2006 and 6.1 percent in 2007, [and that] in the Caucasus the unemployment rate was 13.7 and 11.710" (Markedonov, 2010: 4), we better understand the difficulty in ensuring economic security because of a non-existent economic society. The attractiveness of insurgency groups to local populations resides on the certainty that some basic needs could be fulfilled through them. In a region where the shadow economy employs more people than a regular and legal economy, people will see "shadow economy" as the exit door to a troubled life. In the case of Ciscaucasian ethnic populations, we also have to understand that these individuals regard themselves firstly as part of a community and only after that as singular subjects.

The applicability of human security paradigms is partially conditioned by this structural precondition (what we could call the communitarian clause). That is the main reason why this paper has tried to weave a macro level (economic society) together with a micro level (economic security). Indeed a human security focus on individuals is important to provide an alternative level of analysis to questions that historically have proven to be difficult to account for on a more macro level. Human security offers the possibility of enlarging the type of analyses and allows taking new and more accurate conclusions that should be taken into consideration by the Kremlin when looking at the North Caucasus as an object of political connection.

Submitted in September 2011

Accepted in February 2013 


\section{References}

BAYLIS, John., SMITH, Steve., and OWENS, Patricia. (2008), The Globalization of World Politics - An introduction to international relations. New York: Oxford University Press.

BELL, Daniel. (1975), Ethnicity and Social Change, In: Ethnicity: Theory and Experience, edited by Nathan Glazer and Daniel Moynihan. Massachusetts: Harvard University Press.

BLOKKER, Paul. (2005), Post-Communist Modernization, Transition Studies and Diversity in Europe, European Journal of Social Theory, vol. 8, n 4, pp. 503-525.

BLUM, Douglas W. (Ed.). (2008), Russia and Globalization: Identity, Security, and Society in an Era of Change. Maryland: John Hopkins University Press.

BROOKDALE INSTITUTE. (2003), The Social and Economic Situation in Countries of the FSU Case Studies of Ukraine, Russia \& Moldova, Brookdale/ONAD Information System, August 20, $<$ http://www.claimscon.org/forms/allocations/The\%20Social\%20and_FSU\%20JDC_.pdf>.

CAUCASUS REPORT. (2010), Medvedev Creates New North Caucasus Federal District, Radio Free Europe/Radio Liberty, January 20, <http://www.rferl.org/content/Medvedev_Creates_ New_North_Caucasus_Federal_District/1934705.html>.

COENE, Frederik. (2009), The Caucasus: An Introduction. New York: Routledge.

COMMISSION ON HUMAN SECURITY. (2003), Human Security Now - Report. New York: Communications Development Incorporated.

COMMODITIES STREET JOURNAL. (n.d.), Russia, ID Report - News for Intelligent Living, $<$ http://commoditiesstreetjournal.com/commodity-country-profiles/russia/>.

CORNELL, Svante E., and STARR, Frederick S. (2006), The Caucasus: A Challenge for Europe, Central Asia - Caucasus Institute and Silk Road Studies Program, pp. 1-85.

Dzutsev, Valery. (2010), Khloponin's Innovative ApproachtotheNorthCaucasusFaces Uphill Struggle, Eurasia Daily Monitor, vol. $7, \mathrm{n}^{\circ} 129,<\mathrm{http}: / / \mathrm{www}$.jamestown.org/single/?no_cache $=1 \& \mathrm{tx}$ _ ttnews\%5Btt_news\%5D=36581\&tx_ttnews\%5BbackPid\%5D $=7 \& \mathrm{cHash}=435 \mathrm{f} 32 \mathrm{fe} 32>$.

FREEZE, Gregory L. (2009), Russia: A History. New York: Oxford University Press.

FREITAS, João Teixeira de. (2012), Uma visão sobre o neo-patrimonialismo russo na era póssoviética, Observatório de Segurança Humana, pp. 1-15, <http://www.segurancahumana. $\mathrm{eu} / \mathrm{data} / \mathrm{res} / 27 / 1826 . \mathrm{pdf}>$.

GAMMER, Moshe. (2005), The Lone Wolf and the Bear: Three Centuries of Chechen Defiance - A History. London: C. Hurst \& Co Publishers Ltd.

GOBLE, Paul. (2009), Moscow to Cut Subsidies to North Caucasus, Shifting Them to Russian Region, Kozak Says, Window on Eurasia, September 13, <http://windowoneurasia. blogspot.com/2009/09/window-on-eurasia-moscow-to-cut.html>.

HALBACH, Uwe. (2010), Russia's Internal Abroad: The North Caucasus as an Emergency Zone at the Edge of Europe, German Institute for International and Security Affairs, Research Paper $\mathrm{n}^{\circ}$ 5, pp. 1-34, <http://www.swp-berlin.org/fileadmin/contents/products/research_ papers/2010_RP_05_hlb_ks.pdf> 
HALE, Henry E. (2008), The foundations of ethnic politics - Separatism of States and Nations in Eurasia and the World. New York: Cambridge University Press. . (2000), The parade of sovereignties: Testing Theories of Secession in the Soviet Settlement, British Journal of Political Science, vol. 30, $\mathrm{n}^{\mathrm{o}}$ 1, pp. 31-56.

HOROWITZ, Donald L. (2000), Ethnic Groups in Conflict. Berkeley: University of California Press.

HUMAN DEVELOPMENT NETWORK. (2005), Peace, Human Security and Human Development in the Philippines, <http://hdn.org.ph/wp-content/uploads/2008/11/Highlights-ofPHDR-2005.pdf $>$.

HUNTINGTON, Samuel P. (1993), The Third Wave: Democratization in the Late Twentieth Century. Oklahoma: University of Oklahoma Press.

INDEX MUNDI. (2011), GDP (purchasing power parity - Billion \$) - Russia, <http://www. indexmundi.com/g/g.aspx?v $=65 \& \mathrm{c}=\mathrm{rs} \& \mathrm{l}=\mathrm{en}>$.

JACKSON, Alexander. (2010), Tackling the North Caucasus Insurgency: Development or Rhetoric?, Caucasian Review of International Affairs-Caucasus Update, $\mathrm{n}^{\circ}$ 61, January 11, <http:// cria-online.org/CU_-_file_-_article_-_sid_-_81.html>

KING, Charles. (2008), The Ghost of Freedom - A History of the Caucasus. New York: Oxford University Press.

KÖRBEL, Thomas. (2009), La Russie peut-elle apaiser le Caucase du Nord?, Actualités de la Russie et de la CEI - Institut de Relations Internationales et Stratégiques, $\mathrm{n}^{\mathrm{o}}$ 17, pp. 1-6, < http://www.iris-france.org/docs/pdf/actu_cei/2009-07-01.pdf>.

LEAHY, Kevin Daniel. (2009), The Global Economic Crisis: Implication for Russian Policy in the North Caucasus, Central Asia-Caucasus Institute Analyst, March 25, <http://www. cacianalyst.org/?q=node/5067 > .

LINZ, Juan., and STEPAN, Alfred. (1996), Problems of Democratic Transition and Consolidation: Southern Europe, South America, and Post-Communist Europe. Baltimore: The John Hopkins University Press.

LIONO, Alexandru. (2000), Economic Survival Strategies in North Caucasus, Circassian World, $<$ http://www.circassianworld.com/economic.html $>$.

LOPES, Tiago Ferreira. (2010), Honor, faith, politics and complexity from Cherkessk to Makhachkala - Analysis to the rebirth of ethno-religious nationalisms in North Caucasus, Daxiyangguo - Revista Portuguesa de Estudos Asiáticos, n ${ }^{0}$ 15, pp. 3-32.

LORDKIPANIDZE, Vazha., and TOTADZE, Anzor. (Ed.). (2010), The Population of the Caucasus. New York: Nova Science Publishers.

MARKEDONOV, Sergey. (2009), The Big Caucasus - Consequences of the "Five Day War", Threats and Political Prospects, International Centre for Black Sea Studies - Xenophon Paper, $\mathrm{n}^{\mathrm{0}}$ 7, pp. 1-75, < http://cis.uchicago.edu/sites/cis.uchicago.edu/files/resources/THE BIG CAUCASUS.pdf $>$.

(2010), Radical Islam in the North Caucasus: Evolving Threats, Challenges, and Prospects - A Report of the CSIS Russia and Eurasia Program, Center 
for Strategic \& International Studies, pp. 1-13, < http://csis.org/files/publication/101122_ Markedonov_RadicalIslam_Web.pdf>

MATVEEVA, Anna. (1999), The North Caucasus - Russia's Fragile Borderland. London: The Royal Institute of International Affairs.

MELVIN, Neil. (2007), Building Stability in the North Caucasus - Ways forward for Russia and the European Union, Stockholm International Peace Research Institute, Policy Paper $\mathrm{n}^{\circ}$ 16, pp. $1-58$.

MENDELSON, Sarah., MALARKEY, Matthew., and MOORE, Lucy. (2010), Violence in North Caucasus - Spring 2010: On the Rise Again?, Center for Strategic and International Studies - Human Rights and Security Initiative, pp. 1-24, < http://csis.org/files/ publication/100513_Violence_in_the_North_Caucasus_Spring_2010.pdf $>$.

PEROVIC, Jeronim. (2006), The North Caucasus on the Brink, Swiss Federal Institute of Technology Zurich, pp. 1-31, < http://dspace.cigilibrary.org/jspui/bitstream/123456789/7580/1/The North Caucasus on the Brink.pdf?1>.

PIPES, Richard. (1995), Russia under the Old Regime. London: Penguin Books.

PRZEWORSKI, Adam., and Limongi, Fernando. (1997), Modernization: Theories and Facts, World Politics, vol. 49, n 2, pp. 155-183.

SERVICE, Robert W. (1997), A History of Twentieth-Century Russia. London: Penguin Books.

SMITH, Graham. (1999), The Post-Soviet States: Mapping the Politics of Transition. Oxford: Oxford University Press.

UNITED NATIONS EDUCATION, SCIENTIFIC AND CULTURAL ORGANIZATION. (2008), Human Security: Approaches and Challenges. Paris: Stedi Media.

UNITED NATIONS. (2009), Human Security in Theory and Practice - Application of the Human Security Concept and The United Nations Trust Fund for Human Security. New York: Office for the Coordination of Humanitarian Affairs.

VATCHAGAEV, Mairbek. (2010), Kremlin Offers Money and Financial Incentives to Change the Mood in the North Caucasus, Eurasia Daily Monitor, vol. 7, $\mathrm{n}^{\circ}$ 136, <http://www. jamestown.org/single/?no_cache $=1 \&$ tx_ttnews\%5Btt_news\%5D $=36625>$.

WASSERSTEIN, Bernard. (2007), Barbarism \& Civilization - A History of Europe in our Time. New York: Oxford University Press.

WEGREN, Stephen. (2003), Neoliberalism and Market Reforms in Rural Russia, In: Dilemmas of Transition in Post-Soviet Countries, edited by Joel Moses. Chicago: Burnham Publishers.

WORLD BANK. (2008), Russian Economic Report, $\mathrm{n}^{\mathrm{o}}$ 17, <http://siteresources.worldbank.org/ INTRUSSIANFEDERATION/Resources/rer17_eng.pdf $>$.

(2012), Poverty headcount ratio at national poverty line $(\%$ of population) - Russia, <http://data.worldbank.org/indicator/SI.POV.NAHC/countries/ $\mathrm{RU}$ ?display $=$ graph $>$. 


\section{Notes}

1 In 2008 the medium unemployment rate registered across the Russian Federation was lower than 5.5\%. For more accurate information on macroeconomic indicators in the Russian Federation in 2008, see World Bank (2008).

2 Military District is based in Rostov-on-Don (capital of the Rostov Oblast) and ensures the security for all administrative constituencies of the North Caucasus Federal District and of the Southern Federal District. To better understand the origin and nature of the North Caucasus Military District, we suggest: http://www.globalsecurity.org/military/world/russia/vo-northcaucasian.htm

3 Similar to the North Caucasus Military District, the North Caucasus Economic Region includes all the administrative constituencies of the North Caucasus Federal District and of the Southern Federal District. This economic region is part of the European-Russia Economic Zone. Information about this subject is scarce, but a good start to understand it is: http://www. museumstuff.com/learn/topics/North_Caucasus_economic_region

4 The main measures appointed to accomplish this goal in Khloponin's proposal are the "construction of highways across the North Caucasus, invigorating the development of railroads to the South Caucasus, construction of ports on the Dagestani coast of the Caspian Sea and creating a transport corridor to Iran" (Dzutsev, 2010).

5 At the end of the 1990s, a series of socio-economic programmes were approved, such as "Measures for State Support for the Social and Economic Development in Kabardino-Balkaria or State Support for the Social and Economic Development in North Ossetia-Alania". Despite the political intentions, the majority of the programmes have proven their inefficiency in the production of concrete results. To read more about this topic, see: Matveeva (1999).

6 On 12 August 2010, Ramzan Kadyrov proposed that only the President of the Russian Federation could use that title, changing his own title as President of the Chechen republic to Head of the Chechen republic. Yunus-Bek Yevkurov, President of the Ingushetia republic, had supported this idea as well as the current President of the Karachaevo-Cherkessia Republic, Boris Ebzeev. Prior to that, in 2005, Alexander Dzasokhov had already changed the title of President of the North Ossetia-Alania republic to Head of the republic. To read more about this subject, see: http://www.themoscowtimes.com/news/article/regional-bosses-seek-new-title/412431.html

7 In a political document presented in Moscow, Vladimir Putin's grandiose plan to create 400,000 jobs in ten years in the region has been reviewed to a smaller number of 160,000 jobs. This programme wasn't considered a priority to the Kremlin endangering its nearby fulfillment. To read more about this turnover in Vladimir Putin's promises, see: http:// www.jamestown.org/programs/ncw/single/?tx_ttnews\%5Btt_news\%5D =36636\&tx_ ttnews $\% 5$ BbackPid\%5D=423\&no_cache $=1$

8 For a developed reading about the campaigns in the Caucasus and the résistance of the ethnic groups, see Gammer (2005).

9 Lopes (2010).

10 Unemployment rates in Kalmykia, Krasnodar, Rostov and Stavropol are much lower than the ones registered in the other predominantly non-Russian republics. The numbers that Markedonov presents in its research results from an average calculation that includes those four predominantly Russian regions. 